\title{
ANALISIS IMPLEMENTASI E-GOVERNMENT DALAM MENINGKATAN KINERJA PELAYANAN PUBLIK PADA PEMERINTAH DAERAH KABUPATEN CIAMIS
}

\author{
Ahmad Juliarso \\ Fakultas Ilmu Sosial dan Ilmu Politik, Universitas Galuh \\ Ciamis, Jawa Barat, Inonesia \\ ajuliarso@gmail.com
}

\begin{abstract}
ABSTRAK
Implementasi e-government dalam pelayanan publik pada Pemerintah Daerah diharapkan dapat menghasilkan pelayanan publik yang lebih cepat, lebih baik, dan lebih efisien, serta dapat meningkatkan penerapan prinsip prinsip tata kepemerintahan yang baik (good governance). Penelitian ini bertujuan untuk menganalisis implementasi e-government dalam hal pelayanan publik di Kabupaten Ciamis, yang didasarkan pada evaluasi pemeringkatan e-government Indonesia, analisis indeks kepuasan masyarakat terhadap pelayanan publik berbasis e-government, dan evaluasi implementasi e-government. Adapun metode yang digunakan dalam penelitian ini adalah menggunakan pendekatan deskriptif analisis. Berdasarkan hasil penelitian, kemajuan penerapan e-government di Pemerintah Daerah Kabupaten Ciamis adalah telah banyak menggunakan perangkat lunak aplikasi pada situs web www.ciamiskab.go.id dan sistem informasi lainnya yang menunjang pelaksanaan tugas kantor maupun pelayanan kepada masyarakat. Adapun kelemahannya adalah terbatasnya sumber daya manusia yang mampu untuk mengoperasikan dan mengelola aplikasi tersebut. Maka dari itu, guna meningkatkan pengelolaan e-governemnt diberikan rekomendasi untuk dilakukan peningkatan kapasitas sumber daya manusia dalam mengelola aplikasi dan mengintegrasikan sistem informasi dalam pengelolaan $e$ government tersebut dalam rangka peningkatan kinerja pelayanan publik di Pemerintah Daerah Kabupaten Ciamis.
\end{abstract}

Kata kunci: e-government, Pelayanan Publik,Integrasi Sistem Informasi.

\section{ABSTRACT}

The implementation of e-government in public services at local governments is expected to result in faster, better, and more efficient public services, as well as to improve the application of the principles of good governance. This study aims to analyze the implementation of e-government in terms of public services in Ciamis Regency, which is based on the evaluation of the ranking of Indonesian e-government, the analysis of the index of community satisfaction with e-government-based public services, and evaluation of the implementation of e-government. The method used in this research is to use a descriptive analysis approach. Based on the research results, the progress of the implementation of e-government in the Ciamis Regency Government is that it has used a lot of application software on the website www.ciamiskab.go.id and other information systems that support the implementation of office tasks and services to the community. The weakness is the limited human resources who are able to operate and manage the application. Therefore, in order to improve e-government management, recommendations are made to increase the capacity of human resources in managing applications and integrate information systems in e-government management in order to improve the performance of public services in the Ciamis Regency Regional Government.

Keywords: e-government, public services, information system integration.

\section{PENDAHULUAN}

Implementasi e-government untuk pelayanan publik pada tataran pemerintah Daerah diharapkan dapat menghasilkan pelayanan publik yang lebih cepat, lebih baik, dan lebih efisien, serta dapat meningkatkan penerapan prinsip-prinsip tata kepemerintahan yang baik (good governance). Pemerintah Daerah bekerja secara optimal dan terbuka kepada masyarakat, sehingga dapat mempercepat tercapainya visi pemerintah untuk dapat mewujudkan pelayanan prima kepada seluruh 
masyarakat. Website Pemerintah Daerah merupakan sarana informasi yang sangat penting pada era keterbukaan informasi publik pada saat ini. Melalui website yang dimiliki, Pemerintah Daerah dapat menginformasikan kepada publik/masyarakat tentang berbagai hal yang berkaitan dengan penyelenggaraan urusan pemerintahan dan pelaksanaan pembangunan, sehingga publik/masyarakat dapat mengetahui segala informasi dan perkembangan yang terjadi di daerahnya. Demikian halnya pada Pemerintah Daerah Kabupaten Ciamis, selain memiliki website Pemerintah Daerah, beberapa SKPD lingkup Pemerintah Daerah Kabupaten Ciamis juga memiliki website tersendiri, sehingga informasi yang berkaitan dengan program, kegiatan, tugas dan fungsi SKPD dapat diketahui oleh masyarakat melalui website ini.

Domain website yang dimiliki oleh Pemerintah Daerah Kabupaten Ciamis yaitu www.ciamiskab.go.id. Sedangkan Website SKPD sebagaimana dimaksud di atas adalah merupakan subdomain dari Website Pemerintah Daerah Kabupaten Ciamis. Dalam Website SKPD menyediakan berita, profil SKPD, informasi Pembangunan dan lain-lain.

Pada tahun 2017 seluruh SKPD di Kabupaten Ciamis sudah memiliki website yaitu sebanyak 63 (Enampuluh tiga) SKPD dari yang ditargetkan sebanyak 5 (lima) SKPD, Pembuatan/kepemilikan website oleh setiap SKPD merupakan salah satu upaya dalam rangka meningkatkan transparansi atas berbagai informasi kepada masyarakat serta sebagai salah satu program Pemerintah Daerah Kabupaten Ciamis dalam rangka menuju Smart City.

Kemajuan teknologi dan informasi dalam e-government telah mempengaruhi pola manajemen dalam penyelenggaraan pemerintahan. Penggunaan teknologi informasi dalam e-government dapat meningkatkan penerapan prinsip-prinsip tata kepemerintahan yang baik (good governance) dan dapat memberikan pelayanan publik yang lebih cepat dan efisien. Dalam implementasi e-government untuk pelayanan publik, kendala yang sering dihädapi tidak hanya pada ketersediaan teknologi dan dana penunjang operasional, tetapi juga menyangkut berbagai persoalan manajerial yang komplek (Dwiyanto,2006). Salah satu faktor penting dalam keberhasilan implementasi e-government untuk pelayanan publik adalah adanya komitmen pimpinan pemerintahan daerah, dan kompetensi sumberdaya manusia (Faizah, dkk, 2009). Masyarakat dalam hal ini sebagai pelanggan dari pelayanan publik, memiliki harapan agar kinerja penyelenggara pelayanan publik semakin profesional, dan mampu memuaskan masyarakat.

Penelitian ini bertujuan untuk melakukan analisis terhadap implementasi e-government pada Pemerintah Daerah Kabupaten Ciamis dalam kaitannya peningkatan kinerja pelayanan publik. Hasil penelitian ini memberikan informasi tentang kondisi faktual berupa keunggulan dan kelemahan dalam implementasi e-government pada Pemerintah Daerah Kabupaten Ciamis, sehingga dapat memberikan langkah-langkah dalam upaya meningkatkan kinerja pelayanan publik. Berdasarkan faktor dari aspek kelemahan diberikan saran sebagai bahan masukan untuk pengembangan dan implementasi egovernment dalam rangka untuk meningkatkan kinerja pelayanan publik yang prima.

\section{METODE}

Penelitian ini menggunakan metodologi dengan pendekatan deskriptif analisis, berkaitan dengan implementasi e-government dalam rangka peningkatan kinerja pelayanan publik berbasis $e$ government di Kabupaten Ciamis. Pendekatan analisis tersebut didasarkan pada Instruksi Presiden Nomor 3 Tahun 2003 tentang Kebijakan dan Strategi Nasional Pengembangan E-Government dan Peraturan Menteri Pendayagunaan Aparatur Negara dan Reformasi Birokrasi No. 38 Tahun 2012 tentang Pedoman Penilaian Kinerja Unit Pelayanan Publik. Analisis implementasi e-government dalam peningkatan kinerja pelayanan publik di Kabupaten Ciamis. adapun dalam penelitian ini menggunakan 3 (tiga) aspek pendekatan, yaitu :

1. Evaluasi pemeringkatan e-government Indonesia Kabupaten Ciamis. 
2. Analisis indeks kepuasan masyarakat terhadap pelayanan publik berbasis e-government Pemerintah Daerah Kabupaten Ciamis.

3. Evaluasi implementasi e-government Pemerintah Daerah Kabupaten Ciamis.

Evaluasi pemeringkatan e-government Indonesia (PeGI) di Kabupaten Ciamis menggunakan 5 (lima) dimensi, yaitu kebijakan, kelembagaan, infrastruktur, aplikasi, dan perencanaan (Direktorat $E$ government Direktorat Jenderal Aplikasi Informatika, Kementerian Komunikasi dan Informatika RI, 2012). Setiap dimensi dalam PeGI dijabarkan kedalam beberapa kriteria atau atribut (Fitriansyah, dkk., 2013). Penilaian kualitas pelayanan publik berbasis e- government menggunakan dimensi dan atribut dalam PeGI di Kabupaten Ciamis disesuaikan dengan Peraturan Menteri Pemdayagunaan Aparatur Negara dan Reformasi Birokrasi Nomor 38 Tahun 2012 tentang Pedoman Penilaian Kinerja Unit Pelayanan Publik. Sesuai dengan Peraturan Menteri PAN dan Reformasi Birokrasi tersebut, perlu dianalisis indeks kepuasan masyarakat terhadap pelayanan publik berbasis e-government menggunakan Keputusan Menteri Pendayagunaan Aparatur Negara Nomor Kep/25/M.Pan/2/2004 tentang Pedoman Umum Penyusunan Indeks Kepuasan Masyarakat Unit Pelayanan Instansi Pemerintah. Analisis Indeks Kepuasan Masyarakat (IKM) pada pelayanan publik berbasis egovernment menggunakan prinsip pelayanan dengan 14 unsur minimal yang sebagai dasar pengukuran IKM. Sedangkan untuk evaluasi implementasi e-government untuk pelayanan publik menggunakan pedoman penilaian sifat transaksi informasi dan pelayanan publik yang disediakan oleh Pemerintah Daerah Kabupaten Ciamis menggunakan 4 (empat) tingkatan, yaitu tingkatan persiapan, pematangan, pemantapan dan pemanfaatan sesuai dengan Instruksi Presiden Nomor 3 Tahun 2003. Adapun tujuan dari penelitian ini yaitu untuk mengetahui pemeringkatan dalam aspek pengembangan dan implementasi e-government (Sosiawān,2008). Selanjutnya dalam aspek implementasi $e$ government dievaluasi juga terhadap aspek pelayanan publik yang bersifat Government to Government (G2G), Government to Business $(\mathrm{G} 2 \mathrm{~B})$, atau Government to Consumers $(\mathrm{G} 2 \mathrm{C})$.

Penelitian ini dilakukan pada beberapa SKPD Pemerintah Daerah Kabupaten Ciamis. Data yang digunakan dalam penelitian ini adalah data pengamatan langsung, hasil survey dan wawancara berkaitan sistem, aplikasi dan data transaksional dari situs e-government www.ciamiskab.go.id. Data hasil survey menggunakan data sekunder yang berasal dari Bagian Pengolahan Data Elektronik (PDE) dan Badan Pelayanan Perijinan Terpadu dan Penanaman Modal (BPPTPM) Kabupaten Ciamis. Data kondisi aplikasi pada pengelolaan e-government Kabupaten Ciamis berasal dari Bagian PDE pada bulan Oktober 2017. Data terkait dengan kondisi faktual e-government Kabupaten Ciamis menggunakan pengamatan langsung pada situs www.ciamiskab.go.id pada bulan Oktober 2017. Untuk data kepuasan masyarakat terhadap kinerja pelayanan publik di Kabupaten Ciamis menggunakan data responden dari para pelanggan yang telah melakukan transaksi perijinan pada BPPTPM secara online pada kondisi sampai dengan Oktober 2017.

\section{PEMBAHASAN}

\section{Pelayanan Publik Berbasis E- Government}

Penggunaan e-government untuk pelayanan publik bertujuan untuk memberikan pelayanan publik secara penuh kepada masyarakat dalam bentuk penyampaian informasi meliputi penyampaian informasi, program kerja, visi misi, pelayanan publik, hingga hubungan ke setiap Satuan Kerja Pemerintah Kerja (SKPD), termasuk ke pihak eksternal. Peran strategis penggunaan e-government juga untuk menemukenali bidang-bidang unggulan yang dimiliki dan mempunyai potensi untuk dikembangkan dengan memanfaatkan sistem jaringan melalui internet/intranet. Pelayanan publik yang berkualitas merupakan amanat dari UU RI Nomor 25 tahun 2009 tentang Pelayanan Publik yang mengatur prinsip-prinsip pemerintahan yang baik agar fungsi-fungsi pemerintahan dalam 
melaksanakan pelayanan publik dapat berjalan efektif. Penjabaran penilaian kinerja pelayanan publik diatur dalam Peraturan Menteri PAN dan Reformasi Birokrasi Nomor 8 Tahun 2012 tentang Pedoman Penilaian Kinerja Unit Pelayanan Publik. Sesuai dengan UU Pelayanan Publik, pelayanan publik dinyatakan sebagai kegiatan atau rangkaian kegiatan dalam rangka pemenuhan kebutuhan pelayanan sesuai dengan peraturan perundang-undangan bagi setiap warga negara dan penduduk atas barang, jasa, dan/atau pelayanan administrasi yang disediakan oleh penyelenggara pelayanan publik. Pelayanan publik dari penyelenggara pemerintah menggunakan standar pelayanan yang merupakan tolok ukur yang dipergunakan sebagai pedoman penyelenggaraan pelayanan, serta acuan penilaian kualitas pelayanan sebagai kewajiban dan janji pemerintah kepada masyarakat dalam rangka pelayanan yang berkualitas, cepat, mudah, terjangkau, dan terukur.

Pelayanan publik berbasis e-government dapat mempermudah masyarakat untuk mengakses berbagai layanan tanpa harus datang langsung ke kantor pemerintahan (Junaidi, 2011). Kelengkapan dan keterbukaan informasi pada e-government yang dapat diakses akan mendorong terciptanya good governance dalam pemerintahan melalui peningkatan transparansi dan akuntabilitas pada lembagalembaga layanan publik. E-government juga diharapkan dapat meningkatkan produktivitas dan efisiensi birokrasi, sehingga dapat meningkatkan kreatifitas dan inovasi, baik dari pihak penyelenggara pelayanan publik ataupun bagi masyarakat. Penerapan e-government untuk pelayanan publik dapat meningkatkan kemudahan dan efisiensi. Misalnya pada layanan sistem Layanan Pengadaan Barang/Jasa Secara Elektronik (LPSE) telah terbukti menghasilkan efisiensi yang sangat tinggi. Penerapan satu jenis layanan berbasis e-government pada pemerintahan juga telah dapat memberikan manfaatnya dari segi efisiensi dan produktifitas. Berdasarkan Inpres Nomor 3 Tahun 2009 tentang Kebijakan dan Strategi Nasional Pengembangan E-Government, pemerintah harus mampu memenuhi dua modalitas tuntutan maşyarakat yang berbeda namun berkaitan erat, yaitu :

1. Masyarakat menuntut pelayanan publik yang memenuhi kepentingan masyarakat luas di seluruh wilayah Indonesia, dapat diandalkan dan terpercaya, serta mudah dijangkau secara interaktif;

2. Masyarakat menginginkan agar aspirasi mereka didengar, sehingga pemerintah harus memfasilitasi partisipasi dan dialog publik di dalam perumusan kebijakan negara.

Untuk mengembangkan sistem manajemen dengan memanfaatkan kemajuan teknologi informasi dan komunikasi, maka pemerintah kota/daerah secara otonom harus dapat melaksanakan proses transformasi menuju e-government. Sesuai definisi dari Bank Dunia, e-government merupakan penggunaan teknologi informasi oleh pemerintah, yang memungkinkan pemerintah untuk mentransformasikan hubungan dengan masyarakat, dunia bisnis dan pihak yang berkepentingan.

Sesuai dengan Inpres Nomor 3 Tahun 2009, pengembangan e-government diarahkan untuk mencapai empat tujuan, yaitu ;

1. Pembentukan jaringan informasi dan transaksi pelayanan publik yang memiliki kualitas dan lingkup yang dapat memuaskan masyarakat luas serta dapat terjangkau di seluruh wilayah Indonesia pada setiap saat tanpa dibatasi oleh sekat waktu dan biaya yang terjangkau oleh masyarakat.

2. Pembentukan hubungan interaktif dengan dunia usaha untuk meningkatkan perkembangan perekonomian nasional dan memperkuat kemampuan menghadapi perubahan dan persaingan perdagangan internasional.

3. Pembentukan mekanisme dan saluran komunikasi dengan lembaga-lembaga negara serta penyediaan fasilitas dialog publik bagi masyarakat agar dapat berpartisipasi dalam perumusan kebijakan negara. 
4. Pembentukan sistem manajemen dan proses kerja yang transparan dan efisien serta memperlancar transaksi dan layanan antar lembaga pemerintah dan pemerintah daerah otonom.

\section{Evaluasi Pemeringkatan e-Government Indonesia}

Evaluasi untuk pemeringkatan e-government Indonesia (PeGI) mengguna kan lima dimensi yang dikaji, yaitu kebijakan, kelembagaan, infrastruktur, aplikasi, dan perencanaan. Masing-masing dimensi memiliki bobot yang sama dalam penilaian karena semuanya dianggap penting, saling terkait, dan saling menunjang antara satu dengan yang lainnya (Direktorat E-Government Direktorat Jenderal Aplikasi Informatika, Kementerian Komunikasi dan Informatika RI, 2012). Setiap dimensi dalam PeGI dijabarkan kedalam beberapa kriteria atau atribut.

1. Kebijakan. Dimensi kebijakan berhubungan dengan produk hukum dan dokumen resmi sebagai pedoman dan arahan untuk mendorong pemanfaatan Teknologi Informasi dan Komunikasi (TIK).

2. Kelembagaan. Dimensi kelembagaan berhubungan dengan keberadaan organisasi yang berwenang dan bertanggung jawab atas pengembangan dan pemanfaatan TIK.

3. Infrastruktur. Dimensi infrastruktur berhubungan dengan sarana danprasarana yang mendukung pengembangan dan pemanfaatan TIK.

4. Aplikasi. Dimensi aplikasi berhubungan dengan ketersediaan dan dimanfaatkannya piranti lunak aplikasi yang mendukung fungsi dasar umum sistem pemerintahan dalam pelayanan publik.

5. Perencanaan. Dimensi perencanaan berhubungan dengan proses perencanaan TIK dan master plan pengembangan TIK.

Dalam melakukan evaluasi terhadap atribut pada PeGI di Pemrintah Daerah Kabupaten Ciamis untuk keperluan penilaian kualitas pelayanan publik berbasis e-government disesuaikan dengan Peraturan Menteri PAN dan Reformasi Birokrasi Nomor 38 tahun 2012 tentang Pedoman Penilaian Kinerja Unit Pelayanan Publik, dan disesuaikan dengan kebutuhan kegiatan e-government dan TIK di Kabupaten Ciamis. Hasil evaluasi berdasarkan data dari isian kuisioner pemeringkatan PeGI Kabupaten Ciamis tahun 2017, keberadaan e-goverment Kabupaten Ciamis untuk kelima dimensi masih sangat kurang, yaitu berada pada angka 1,32. Salah satu faktor yang sangat dominan menyebabkan penilaian berdasarkan PeGI memberikan nilai katagori kurang disebabkan karena masih kurangnya aplikasi-aplikasi yang digunakan dan lemahnya peraturan yang memayungi kebijakan pengelolaan e-government.

Berdasarkan data dari isian kuisioner pemeringkatan e-government Indonesia (PeGI) Kabupaten Ciamis tahun 2017 dan dari hasil pemetaan penggunaan situs pada semua Satuan Kerja Pemerintah Daerah (SKPD), serta evaluasi terhadap atribut dan indikator pada setiap dimensi, diperoleh beberapa faktor utama yang menjadi kelemahan dalam pengembangan dan implementasi $e$ government Kabupaten Ciamis untuk peningkatan kinerja pelayanan publik. Keberhasilan dalam implementasi e-government di Pemerintah Daerah Kabupaten Ciamis tidak hanya tergantung pada infrastruktur komunikasi data dan informasi, melainkan juga pada infrastruktur sistem aplikasi, standarisasi meta data, pengembangan sumber daya manusia, pengembangan prosedur, kebijakan dan peraturan. Berikut beberapa faktor utama pada setiap dimensi yang menjadi kelemahan dalam implementasi e-government untuk pelayanan publik. Faktor utama tersebut menjadi perhatian dalam melakukan perbaikan atau penyempurnaan implementasi e-government yang bertujuan untuk peningkatan kinerja pelayanan publik. 


\section{Kebijakan}

1. Koordinasi kegiatan dan anggaran.

Koordinasi kegiatan dan anggaran untuk pengembangan dan pemanfaatan TIK untuk setiap SKPD sangat berperan untuk melakukan perencanaan dan evaluasi atas efektifitas dan efisiensi anggaran TIK sebagaimana tujuan diselenggarakannya e-government. Sementara pada pemerintah daerah Kabupaten Ciamis, diketahui koordinasi untuk pengembangan dan pemanfaatan TIK masih kurang baik, dan ketersediaan anggaran untuk mendukung kegiatan tersebut masih belum optimal.

2. Standard Operating Procedure (SOP) pengadaan, perencanaan, pemanfaatan dan pengendalian.

Penggunaan SOP pengadaan, perencanaan, pemanfaatan dan pengendalian terkait dengan pengembangan dan pengelolaan e-government Pemerintah Daerah akan mendorong keberhasilan dalam penyelenggaraan pengadaan dan pemanfaatan TIK agar setiap SKPD dapat menyesuaikan dengan standar anggaran dan operasional yang telah ditentukan. Berdasarkan hasil penelitian diketahui SOP terkait dengan pengembangan dan pengelolaan e-government pada pemerintah daerah masih belum tersedia secara menyeluruh.

\section{Kelembagaan}

1. Organisasi fungsional.

Belum adanya organisasi fungsional seperti Dewan TIK pada Pemerintah Daerah Kabupaten Ciamis sebagaimana pengarahan dari Kementrian Komunikasi dan Informasi pada Peraturan Menteri Kominfo Nomor 41 Tahun 2007 (tentang Panduan Umum Tata Kelola Teknologi Informasi dan Komunikasi Nasional) beresiko banyak usulan kebijakan dari pejabat Eselon 3 tidak bisa menjangkau ke seluruh SKPD yang sebagian besar berada di Eselon 2.

2. Lembaga khusus yang menangani TIK.

Pemerintah Daerah seharusnya memiliki sebuah lembaga khusus yang menangani TIK untuk pengelolaan e-government. Sehingga kewenangan pengelolaan TIK menjadi jelas, apakah pada Bagian Kominfo, Bagian PDE ataupun Bagian Humas. Keberadaan lembaga ini akan memberikan kontrol atas pengembangan dan pemanfaatan TIK, serta kontrol anggaran secara terintegrasi agar dapat dilaksanakan dengan baik, dan mampu menyediakan e-government yang efektif dan efisien di lingkungan Pemerintah Daerah. Dalam hal ini pemerintah daerah Kabupaten Ciamis belum memiliki lembaga khusus yang menangani TIK dalam pengelolaan $e$ government. Sehingga pelaksanaannya masih diserahkan kepada masing-masing operator di SKPD.

3. Tenaga teknis dalam bidang TIK.

Adanya tenaga teknis programer, analis sistem dan teknisi jaringan yang cukup disertai dengan pelatihan berjenjang dapat menunjang keberhasilan layanan infrastruktur TIK. Pada Pemerintah Daerah Kabupaten Ciamis sendiri, ditemukan masih kurangnya tenaga teknis dalam pengelolaan TIK itu sendiri.

\section{Aplikasi}

Link e-government. Adanya link e-government ke unit lain sampai tingkat kecamatan dan desa, maka infrastruktur yang ada dapat dimanfaatkan secara optimal untuk kebutuhan e-government. Sampai saat ini, pemerintah daerah kabupaten Ciamis sudah memiliki beberapa link yang dapat digunakan dalam urusan pemerintahan, misalnya adanya link Siskeudes, memudahkan pemerintah 
Kebijakan: Jurnal Ilmu Administrasi

Volume 10, Nomor 1, Januari 2019

E-ISSN: 2656-2820

P-ISSN 1829-5762

Desa untuk mengelola keuangan desa dan melaporkan berbagai laporan keuangan yang digunakan oleh desa.

\section{Infrastruktur}

1. Pengelolaan bandwidth.

Pengelolaan bandwidth sudah dilakukan secara terintegrasi, sehingga bandwidth yang tersedia dapat digunakan secara optimal yang dapat digunakan oleh setiap SKPD sesuai dengan kebutuhan.

2. Perangkat akses, server dan storage.

Belum adanya data center yang sesuai dengan standar, sehingga kebutuhan perangkat untuk akses, server dan storage belum dapat dikelola oleh SKPD tertentu, misalnya pada Kominfo, PDE maupun Humas. Padahal Pengelolaan data center secara mandiri akan mereduksi kerawanan keamanan informasi.

\section{Perencanaan}

1. Business Continuity Plan pengelolaan infrastruktur TIK.

Business Continuity Plan pengelolaan infrastruktur TIK perlu diadakan, sehingga jika terjadi kegagalan dalam layanan dapat segera diatasi dengan tindakan yang cepat, akurat dan efektif untuk menjamin keberlangsungan sistem.

2. Koordinasi pengusulan kegiatan TIK SKPD.

Koordinasi pengusulan kegiatan TIK SKPD perlu dilakukan agar tidak menyulitkan pengambil kebijakan untuk melakukan optimalisasi anggaran di sektor TIK.

3. Fungsi perencanaan dan kontrol.

Lemahnya fungsi perencanaan dan kontrol dapat beresiko antara lain implementasi TIK tidak dapat terukur secara langsung dalam menunjang misi pemerintahan kota, ketimpangan dalam implementasi TIK di unit-unit di lingkungan Pemerintah Daerah Kabupaten Ciamis, ketidakseragaman standar teknologi, kebijakan dan kewajaran harga dalam pelaksanaan kegiatan TIK di SKPD, redundansi kegiatan terkait TIK, yang sebenarnya dapat diintegrasikan, dan tidak terintegrasinya kegiatan-kegiatan TI.

4. Fungsi monitoring dan evaluasi TIK.

Kegiatan monitoring dan evaluasi TIK dalam implementasi e-government dapat mengatasi adanya kesulitan untuk keberlangsungan aplikasi dalam jangka panjang, sehingga dapat diketahui secara jelas kondisi dari implementasi TIK dalam pengelolaan e-government.

\section{Analisis IKM Terhadap Pelayanan Publik Berbasis E-Government}

Berbagai jenis pelayanan publik Pemerintah Daerah Kabupaten Ciamis telah dilaksanakan melalui sistem pelayanan berbasis e-government menggunakan fasilitas TIK. Sistem ini merupakan inovasi untuk memberikan kemudahan dalam percepatan layanan. Salah satu pelayanan publik berbasis e-government di Kabupaten Ciamis adalah layanan perijinan dan investasi yang telah menggunakan aplikasi perijinan yang berbasis web. Dengan penggunaan aplikasi ini, maka diharapkan mampu memberikan pelayanan kepada masyarakat yang lebih baik dan optimal, sehingga kebutuhan akan informasi yang berkaitan dengan perijinan dapattersampaikan kepada masyarakat dengan cepat, benar dan mudah. Dukungan TIK pada e-government dapat memberikan akses informasi yang lebih luas kepada masyarakat, dan masyarakat dapat menyampaikan keluhan secara online. Otomatisasi dengan didukung suatu Sistem Informasi Pelayanan Perijinan secara terpadu dan online sangat diperlukan guna memberikan pelayanan publik yang berkualitas (prima) sehingga good governance dapat tercapai. 
Indeks Kepuasan Masyarakat (IKM) merupakan suatu ukuran untuk mengukur sejauh mana pemerintah mampu memberikan pelayanan yang terbaik bagi masyarakat dan sejauhmana pemerintahan telah menjalankan perannya dengan baik sesuai dengan indikakor yang telah ditetapkan. Dasar penentuan IKM menggunakan Keputusan Menteri Pendayagunaan Aparatur Negara Nomor Kep./25/M.PAN/2/2004 tentang Indeks Kepuasan Masyarakat. Sesuai dengan keputusan menteri tersebut, IKM merupakan ukuran yang berhubungan dengan tingkat kepuasan masyarakat yang diperoleh dari hasil pengukuran secara kuantitatif dan kualitatif atas pendapat masyarakat dalam memperoleh pelayanan dari aparatur penyelenggara pelayanan publik dengan membandingkan antara harapan dan kebutuhannya. Sesuai dengan keputusan menteri, pengukuran IKM menggunakan 14 unsur penilaian sebagai unsur minimal yang harus dilakukan. Analisis IKM terhadap pelayanan publik berbasis e-government di Pemerintah Daerah Kabupaten Ciamis dalam penelitian ini menggunakan sampel pada Badan Pelayanan Perijian Terpadu dan Penanaman Modal (BPPTPM), meliputi :

1. Bidang Perijinan Kesra dan Lingkungan.

2. Bidang Perijinan Pembangunan.

3. Bidang Perijinan Perekonomian

Mulai tahun 2014, BPPTPM Kabupaten Ciamis telah melakukan survey untuk IKM secara on line melalui situs web yang ada di BPPTPM. Sebagai responden untuk survey secara online adalah para pelanggan yang telah melakukan transaksi perijian pada BPPTPM. Pengumpulan data responden dilakukan oleh BPPTPM Kabupaten Ciamis pada tahun 2017 menggunakan metode survey dengan responden para pelanggan yang telah melakukan transaksi. Berdasarkan data tersebut, hasil IKM pada Badan Pelayanan Perijian Terpadu dan Penanaman Modal (BPPTPM) dapat dilihat pada Tabel 1.

Tabel 1. Hasil IKM Pada BPPTPM di Kabupaten Ciamis

\begin{tabular}{|l|c|c|}
\hline \multicolumn{1}{|c|}{ SKPD BPPT } & Nilai IKM & Mutu \\
\hline Bidang Perijinan Kesra dan Lingkungan & 78,94 & Baik \\
\hline Bidang Perijinan Pembangunan & 77,99 & Baik \\
\hline Bidang Perijinan Perekonomian & 79,31 & Baik \\
\hline
\end{tabular}

\section{Evaluasi Implementasi E- Government Kabupaten Ciamis}

E-government di Kabupaten Ciamis telah dioperasionalkan dengan situs www.ciamiskab.go.id menggunakan sistem jaringan yang interkoneksi antar SKPD untuk melaksanakan tugas dan fungsi pelayanan publik. Pengembangan sistem e-government telah diikuti dengan pembuatan Rencana Induk Pengembangan E-Government Kabupaten Ciamis dan pembangunan infrastruktur yang interkoneksi antar SKPD dengan sistem jaringan, serta pengembangan perangkat keras pendukungnya seperti komputer, server, jaringan, hosting, domain dan lainnya. Pengembangan $e$ government juga diikuti dengan pengem bangan perangkat lunak untuk mendukung para birokrat dalam melaksanakan tugas sehari-hari. Berdasarkan Tabel 1, hasil analisis IKM untuk pelayanan publik yang dilakukan oleh BPPTPM Kabupaten Ciamis menunjukkan baik dan memuaskan masyarakat. Selain itu, BPPT Kabupaten Ciamis sudah menyediakan kotak saran untuk menampung ketidakpuasan atas layanan dari masyarakat. Dari 14 indikator pelayanan yang diteliti terdapat 3 indikator dengan kategori sangat baik, yaitu :

1. Bidang Perijinan Kesra dan Lingkungan, meliputi kemampuan petugas layanan, kenyamanan lingkungan, dan keamanan lingkungan.

2. Bidang Perijinan Pembangunan, meliputi kemampuan petugas layanan. 
Kebijakan: Jurnal Ilmu Administrasi

Volume 10, Nomor 1, Januari 2019

E-ISSN: 2656-2820

P-ISSN 1829-5762

3. Bidang Perijinan Perekonomian, meliputi kemampuan petugas layanan, kenyamanan lingkungan, dan keamanan lingkungan.

Evaluasi implementasi e-government pada Pemerintah Daerah Kabupaten Ciamis yang berhubungan dengan pelayanan publik juga menggunakan evaluasi implementasi e-government didasarkan pada analisis sifat transaksi dan pelayanan publik berbasis e-government melalui domain ciamiskab.go.id. Evaluasi implementasi e-government tersebut bertujuan untuk mengetahui tingkatan pada aspek pengem bangan e-government melalui tingkatan persiapan, pematangan, pemantapan dan pemanfaatan sesuai dengan Inpres Nomor 3 Tahun 2003. Dalam evaluasi implementasi e-government untuk pelaksanakan pelayanan publik juga melakukan transformasi sistem proses kerja manual ke sistem yang berbasis elektronik. Sesuai dengan tujuan dan fungsi e-government, transformasi proses kerja dari sistem secara manual seharusnya terjadi perubahan yang disesuaikan untuk memungkinkan berjalannya sistem elektronik secara efektif dan optimal. Namun demikian, tidak semua proses kerja dapat ditransformsi kedalam sistem elektronik mengingat sifat dan jenis pekerjaan yang mengharuskan mengunakan sistem manual.

Aplikasi untuk mendukung implementasi e-government Pemerintah Daerah Kabupaten Ciamis dilakukan oleh masing- masing SKPD dengan menggunakan link yang berbeda. Ketersediaan link yang menghubungkan pihak Pemerintah Daerah Kabupaten Ciamis dengan institusi atau instansi lain berkait erat dengan kebutuhan dan kepentingan masyarakat merupakan jalan utama menuju tercapai nya tahapan ketiga atau keempat dalam pengembangan dan implementasi e-government. Link hubungan yang di maksud meliputi link Government to Government $(\mathrm{G} 2 \mathrm{G})$, Government to Business (G2B), Government to Consumers (G2C). Jumlah SKPD yang ditempatkan pada situs web ciamiskab.go.id sebanyak 18 SKPD, dengan jumlah situs web SKPD yang dapat diakses sebanyak 16 SKPD, sedangkan 2 situs SKPD tidak dapat diakses. Sesuai Inpres No. 3 Tahun 2003, pengembangan dan implementasi e- government untuk setiap situs web SKPD mayoritas sudah mencapai tingkat 3 atau pemantapan, sedangkan pada tingkat 4 atau pemanfaatan, sebanyak 11 SKPD yang memiliki fasilitas untuk G2G, 3 SKPD untuk G2B, dan 8 SKPD untuk G2C.

Sebagian besar situs web pada setiap SKPD Kabupaten Ciamis telah menyediakan hubungan link antara Pemerintah Daerah Kabupaten Ciamis dengan masyarakat, dan pihak institusi yang bergerak dalam bidang bisnis. Namun hubungan tersebut masih berbentuk link ke institusi yang masih dalam lingkup internal Pemerintah Daerah Kabupaten Ciamis dan hubungan vertikal ke Pemerintah Pusat. Belum dijumpai situs website Kabupaten Ciamis membuat hubungan ke pemerintah daerah lainnya. Ketersediaan umpan balik melalui e-mail atau short messages service (SMS) yang disediakan oleh pihak Pemerintah Daerah Kabupaten Ciamis bagi masyarakat luas merupakan penyediaan sarana untuk menyampaikan berbagai keluhan, kritik dan saran. Hal ini bertujuan agar proses umpan balik dari masyarakat berkaitan dengan keluhan, saran atau permohonan dapat langsung diterima atau di monitor oleh pejabat yang terkait.

\section{KESIMPULAN}

Implementasi e-government untuk pelayanan publik di Pemerintah Daerah Kabupaten Ciamis masih sangat kurang. Namun demikian, pihak pemerintah Daerah Kabupaten Ciamis terus berupaya untuk memperbaikinya. Situs e-government yang dapat diakses untuk mengetahui perkembangan pemerintah daerah Kabupaten Ciamis adalah dengan dapat mengakses ciamiskab.go.id. Kondisi saat ini pengelolaan e-government untuk pelayanan publik masih belum maksimal karena belum adanya unit kerja yang mengkoordinasikan untuk setiap SKPD dalam pengelolaan e-government untuk menjalankan tugas dan fungsinya, dan sejumlah unit kerja lebih mengarah sesuai dengan bidang tugasnya masing-masing. 
Kebijakan: Jurnal Ilmu Administrasi

Volume 10, Nomor 1, Januari 2019

E-ISSN: 2656-2820

P-ISSN 1829-5762

Untuk meningkatkan pengelolaan e-government dalam rangka peningkatan kinerja pelayanan publik di Pemerintah Daerah Kabupaten Ciamis, disarankan menggunakan integrasi sistem informasi dan adanya kelembagaan yang secara khusus mengelola e-government. Untuk dapat melakukan integrasi sistem informasi dalam pengelolaan e-government, perlu adanya perubahan kelembagaan dalam SKPD yang dapat mengkoordinasikan pengelolaan e-government pada semua SKPD. Perubahan kelembagaan dalam pengelolaan e-government untuk pelayanan publik, diberikan dua alternatif sebagai bahan pertimbangan. Pertama kelembagaan SKPD dalam bentuk dinas atau badan yang berperan dalam penyusunan perencanaan dan operasional strategi TIK, dan yang kedua adalah menjadi bagian dari dinas atau badan yang sudah ada suatu SKPD. Dengan memperhatikan beban fungsi koordinasi antar SKPD dan kerja yang akan diemban, serta berdasarkan pedoman struktur organisasi, maka disarankan agar semua bidang atau unit kerja TIK di bawah SKPD Dishubkominfo, sedangkan Unit PDE, Unit Hubungan Masyarakat (Humas) dan Unit Sandi \& Telekonunikasi (Santel) dapat melebur menjadi bidang di bawah SKPD Dishubkominfo (atau nama lain) Kabupaten Ciamis.

\section{DAFTAR PUSTAKA}

Dwiyanto, A. 2006. Mewujudkan Good Governance: Melalui Pelayanan Publik. Yogyakarta : Gadjah Mada University Press.

Faizah, N. \& Sensuse D. I. 2009. Faktor- Faktor Sukses Implementasi E- Government di Empat Kabupaten di Indonesia. Digital Information \& System Conference.

Fitriansyah, A., H. Budiarto, dan J.Santoso. 2013. Metode Pemeringkatan E-Government Indonesia (PEGI) Untuk Audit Tata Kelola Teknologi Informasi. Seminar Nasional Sistem Informasi Indonesia. 24 Desember.

Junaidi. 2011. Dukungan E-Government dalàm Upaya Peningkätan Kualitas Pelayanan Publik di Era Otonomi Daerah : Kasus Best Practices dari Sejumlah Daerah di Indonesia. Proceeding Simposium Nasioal Otonomi Daerah. Lab-ANE FISIP Untirta.

Juric, M.B., R. Loganathan, P. Sarang, dan F. Jennings. 2007. SOA Approach to Integration. Birmingham, B27 6PA, UK : Packt Publishing.

Kushandajani, Standar Pelayanan Minimal (SPM) Dan Peningkatan Pelayanan Publik Di Era Otonomi Daerah, Artikel, 2009.

Pemerintah Daerah Kabupaten Ciamis.2017. Laporan Kinerja Instansi Pemerintah (LKIP) 2016, Raharjo, B. 2001. Membangun E- Government. Bandung : ITB.

Sosiawan, E. A. 2008.Evaluasi Implementasi E-Government pada Situs Web Pemerintah Daerah di Indonesia : Perpektif Content dan Manajemen. http://edw.dosen.upnyk.ac.id.

Utomo, S. D. 2008. Penanganan Pengaduan Masyarakat Mengenai Pelayanan Publik. Jurnal Ilmu Administrasi dan Organisasi, Bisnis dan Birokrasi. 15 (3). 